\title{
Barkhausen Noise Emission of Surfaces after Plasma Beam Machining
}

Anna Mičietová ${ }^{1}$, Miroslav Neslušan $^{1}$, Mária Čilliková1 ${ }^{1}$ Kamil Kolařík ${ }^{2}$

${ }^{1}$ University of Žilina, Faculty of Mechanical Engineering, Univerzitná 1, 01026 Žilina, Slovak Republic; email: anna.micietova@fstroj.utc.sk

${ }^{2}$ ČVUT Praha, Trojanova 13, 12000 Praha 2, Czech Republic

This paper deals with analysis of surface integrity of steel after plasma beam machining (PBM). The paper discusses surface integrity expressed in term of rms values of Barkhausen noise and reports about variables affecting Barkhausen noise emission such as plasma current, nozzle distance, thickness of machined surface and feed speed. The paper demonstrates variable degree of surface hardening due to elevated temperatures and the following rapid cooling. Except magnetic investigation of surface also stress state and structure observation are reported.

Keywords: Plasma Beam Machining, Barkhausen Noise, Surface Hardening

\section{Acknowledgement}

This project is solved under the financial support of KEGA agency (project n. 009ŽU-4/2014 and 005ŽU-4/2014) and project CZ-SK 2013-0017.

\section{References}

[1] MIČIETOVÁ, A. (2007). Nekonvenčné metódy obrábania - výber, využitie, perspektívy, EDIS Žilina, ISBN 97880-8070-775-0.

[2] MIČIETOVÁ, A., MAŇKOVÁ, I., VELÍŠEK, K. (2007). Top trendy v obrábaní, V. čast' - Fyzikálne technológie obrábania. MEDIA/ST, s.r.o., ISBN 80-968954-7-2, Žilina.

[3] MAŇKOVÁ, I. (2000). Progresívne technológie. Vienala, Košice.

[4] ALLEN, D M, et all. (2009). Ion beam focused ion beam and plasma discharged machining. In: CIRP Annals Vol. 58/2, pp. 647-662.

[5] ARNOLD, T., BOHM, G. (2012). Application of atmospheric plasma jet machining for effective surface figuring of SiC. In: Precision Engineering, Vol. 36/4, pp. 546-553.

[6] MIČIETOVÁ, A., NESLUŠAN, M., ČILLIKOVÁ, M. (2013). Influence of surface geometry and structure after non-conventional methods of parting on the following milling operation. In: Manufacturing technology, Vol.13, pp. 199-204.

[7] MIČIETOVÁ, A., NESLUŠAN, M., ČILLIKOVÁ, M. (2013). Residual stresses after thermal methods parting. In: Machines Technologies Materials, Vol. 2, pp. 235 - 240.

[8] VAJDOVÁ, A. el all. (2014). Analysis of surface integrity of parts after non conventional methods of machining. In: Manufacturing technology, Vol.14, pp. 470-474.

[9] KAMEDA, J., RANJAN, R. (1987). Nondestructive evaluation of steels using acoustic and magnetic Barkhausen signals - II. Effect of inter granular impurity segregation. In: Acta Metall., Vol. 35/7, pp. 1527-1531.

[10]BUTTLE, D.J., et all. (1991). Magneto-acoustic and Barkhausen emission: their dependence on dislocations in iron. In: NDT \& E Int., Vol. 24, pp. $47-54$.

[11]GATELIER-ROTHEA, C., et all. (1998). Characterization of pure iron and carbon-iron binary alloy by Barkhausen noise measurements: study of the influence of stress and microstructure. In: Acta Mater. Vol. 46/14, pp. 4873 $-4882$.

[12]RANJAN, R., JILES, C., RASTOGI, $P$. (1987). Magnetic properties of decarburized steels: An investigation of the effects of grain size and carbon content. In: IEEE Trans. Magn., Vol. 23/3, pp.1869-1876.

[13]DURSTOVÁ, Z. et all. (2014). Non-destructive evaluation of ground surfaces made of bearing steel of variable hardness. In: Manufacturing technology, Vol.14, pp. 297-303.

[14]ČILLIKOVÁ, M. et all. (2014). Detection of surface damage after grinding of large case-hardened bearing rings. In: Engineering materials, Vol. 581, pp. 205-210.

[15]BLAOW, M., EVANS, J., SHAW, B. (2005). Magnetic Barkhausen noise: the influence of microstructure and deformation in bending. In: Acta Materialia, Vol. 53, pp.279-287. 
[16]MOORTHY, V. et all. (2001). Evaluation of heat treatment and deformation induced changes in material properties in gear steels using magnetic Barkhausen noise analysis. In: ICBN 03 Tampere, Finland.

[17]BREZANI, J. (2012). Model vzájomných relácií pri termickom rezaní materiálov. PhD. Thesis 2012, University of Žilina.

[18]PANDA, A. et all. (2016). Vibration and experimental comparison of machining process. In: Key Engineering Materials, Vol. 669, pp.179-186, Switzerland.

\section{Paper number: M201637}

Copyright $\odot$ 2016. Published by Manufacturing Technology. All rights reserved. 